\title{
A Comparative Analysis of Administrative Competencies of Male and Female Secondary School Principals in Supervision in Akwa Ibom State, Nigeria
}

\author{
Akpan, Anthony Asuquo \& Eno B. Usoro
}

\begin{abstract}
The study aimed at comparing male and female secondary school principals' administrative competencies in supervision. The sample was made up of 60 male and 60 female principals totaling 120 randomly selected from 10 existing educational zones in Akwa Ibom State, Nigeria. Two hypotheses formed the basis of the study. One tested at 0.05 level of significance using t- test, while the other was tested using analysis of covariance and multiple classification analysis. The results showed that male principals were not significantly better in supervision than their female counterparts. Teaching experience had no significant influence on principals' supervision competencies but administrative experience has great influence on their supervision competencies.
\end{abstract}

\section{Introduction}

Attempt to identify the traits of successful supervision or identification of competencies for successful supervision has been condemned by Sergiovanni and Starrat (1979). They argued that because of the complex, varied and unpredictable nature of supervision has made such attempts difficult. They concluded that adequate maps of successful supervision remain elusive. Their recommendation, however, is an alternative strategy of focusing less on traits and competencies and more on skills and their related domains of knowledge.

Katz (1995) had identified three basic skills upon which he believes successful supervision rest - technical, human and conceptual. Each of the skills domains applies to educational and organizational 
leadership roles of supervisors as well. Explaining each of these skills, Sergiovanni and Starrat (1979) argued that technical skills assume ability to use knowledge, methods and techniques to perform specific tasks. The mechanics associated with writing a lesson plan, developing a study unit, equipping a learning resource centre and filing out an annual report might be examples of technical skills.

Human skills refer to one's ability and judgement in working with and through people. The skill requires self-understanding and acceptance as well as consideration for others. Its knowledge base includes an understanding of, and facility for, leadership effectiveness, adult motivation, attitudinal development, group dynamics and the development of human resources. Conceptual skills refer to the supervisor's ability to view the schools, the district and the educational programme as a whole. This skill includes the effective mapping of the interdependence between the components of the school as an organizational system, the educational programme as an instructional system, and the human organization as a functional humane system. Understanding the interdependencies, which exist between establishing a humane organization, articulating a humane administrative-supervisory system, and developing a humane educational programme, is an example of conceptual skill. Katz argues that, though each of the skill levels is universally present in administrative and supervisory positions, conceptual skills are emphasized more by administrators and technical skills more of supervisory personnel, who are for the most part concerned with the day-by-day work of the school. This relationship is illustrated in figure 1.1.

\section{Skills Needed}

Gellerman (1999) mentioning about substance and style of supervision opined that when the substance of supervision consisted of emphasis on preventing controllable losses - when the substance is relevant to productivity - and when the style of supervision makes that substance easy to tolerate or even to welcome, the effect of that 
supervision upon subordinate behaviour is likely to lead to consistently high levels of productivity.

From this analysis, it followed that both substance and style are indispensable to effective supervision. As conventional wisdom has stressed, one must be able to get along with people; but one must also recognize what they have to do to contribute to productivity, make this clear to them (direction), and to do it all in a manner that preserves their dignity. This adds up to a very demanding role and perhaps that is why the ranks of first-level supervisors have seldom been filled with consistently outstanding performers. By the same token, that is why the recruitment, training, and motivation of effective supervisors was the single best route to sustaining high productivity. Aderonumu and Ehiametalor (1985) outlined the duties of a supervisor to include some of the following:

(1) Planning: Ensuring that the aims of supervision are attained by the application of planning principles to the supervision exercise.

(2) Staffing: Ensuring that staff vacancies in terms of grades and discipline are identified through the process of supervision.

(3) Co-ordination: The supervisor is expected to co-ordinate the efforts of all participants and ensure that by so doing, decision-making becomes a collective responsibility.

(4) Observation: Through supervision, management, staff and students are observed and advice is given for the improvement of habits and standards.

(5) Curriculum Development: The supervisor, through observation can make suggestions for the improvement of the process of curriculum development.

(6) Assessment: Through supervision process, a comparative list of untrained teachers and materials at work are assessed and remedied.

Knezevich (1995) agreed that the principal of a school makes things happen through other people. It is this ability to organize, to allocate 
resources and to stimulate action among others that is needed most. After an extensive study of competencies needed by superintendents, principals, and supervisors, Woodward (1995) concluded that 70 percent of the 2003 competencies deemed essential were common to all three types of administrative positions. The principal in a public school, whether at the elementary or secondary school level, is a counselor of students, the school disciplinarian, the organizer of the schedule, the supervisor of the instructional programme, the pupilrelations representative for the attendance area, the liaison between teachers and the superintendent, the director and evaluator of teaching efforts, the manager of the school facilities, the supervisor of custodial and food-service employees within the building, and a professional leader. Little wonder that this is a demanding position as well as one of considerable significance in determining the direction of public education.

\section{The Problem}

The theoretical concept of the nature of women is still being held by several people today. The society continues to doubt the ability of women to accomplish all tasks in the world of work equally like the male counterpart .The concept of "Anatomy is Destiny" first formulated by Sigmund Freud who maintained that women's psychological make-up has set a limit to what women can and cannot do (Sargent, 1987). According to this theory, since men and women have completely divergent nature, profession should be geared to suit each set. This concept has been only challenged by Hall (1988) who maintained that the assumed women's inability to perform men's dominated profession was rather a submission to cultural norms and societal expectations. She questioned.

First, is there today a difference between women and men as finished product, and if so, how great is this difference? Secondly, granted this difference, how much of it is due to inborn differences between the sexes, how much to the influence of social and domestic functions of the two sexes, how much to the influence of tradition 
and education? And, finally, to what extent is it possible to increase or decrease the hereditary, the social, and the "traditional" differences.

The quest for a clearer understanding of whether male principals are more effective than their female counterparts has spanned several decades, many researchers have already traced the evolution of this enquiry, (Greenfield, 1983). In view of these excruciating demands, there is need to compare the administrative competencies of male and female secondary school principals. Specifically, the study aims at comparing the administrative competencies of male and female secondary school principals in "Supervision".

The purpose of the study was:

1. To identify the administrative competencies among male and female principals.

2. To compare the differences in administrative competencies of male and female principals with respect to supervision.

3. To investigate the influence of teaching and administrative experience on the supervisory competencies of male and female principal.

Two research questions and two null hypotheses were formulated and tasted at 0.05 level of significance.

\section{Hypotheses}

$\mathrm{Ho}_{1}$ : There is no significant difference between the administrative supervisory competencies of male and female principals.

$\mathrm{Ho}_{2}$ : There is no significant difference among school principals of different teaching and administrative experience in their supervisory competencies.

\section{Methodology}

The study was executed using ex-post facto design. The study involved all principals in Government owned Secondary Schools in Akwa Ibom State in Nigeria .No private institution was included 
because most of the principals in private schools are those who have been retired from service and the study specifically sought to find out the supervisory competencies, and the effect of teaching and administrative experience of principals on supervisory competencies. The sample was made up of 120 principals from the ten (10) existing educational zones in Akwa Ibom State of Nigeria. There were sixty (60) female principals and one hundred and eighty (180) male principals in the State Secondary Schools. The researcher accepted the sixty female principals and randomly selected sixty additional male principals from one hundred and eighty by stratifying them into the ten existing educational zones in the State. In each zone, six male principals were randomly drawn. Therefore sixty male and sixty female principals making a total of one hundred and twenty formed the sample for the study.

The principals Administrative Competency Questionnaire (PACQ) was developed and used for gathering data. The PACQ consisted of the demographic information of the respondents specifically seeking "teaching" and "administrative experiences". The second part on supervisory competencies consisted of fifteen items grouped and laid out for responses under Strongly Agree (SA), Agree (A), Disagree (D) and Strongly Disagree (SD). The instrument (PACQ) was face validated by experts in Educational management and planning department of the University of Uyo.. The reliability coefficient of the items involved in the instrument was calculated through pilot test. The instrument was administered on 10 respondents ( 5 male and 5 female principals) from 10 secondary schools other than the ones used for the study. The reliability index of the test was 0.85 using Kuder Richardson 21. The respondent's reaction to each of the items in the second section of the instrument was scored in the Likert type scale by giving 4 point for Strongly Agree, 3 points for Agree, 2 points for Disagree and 1 point for Strongly Disagree. The data generated in the study were analyzed using t-test comparison of means. Hypothesis one (1) was tested using the t-test statistics, while hypothesis two (2) was tested using Analysis of Variance (ANOVA), f-test statistic. 


\section{Result}

In this section, the presentation of data and results was organized around the research questions and statistical hypotheses that guided the study. Table 1 showed that the mean performance of male and female principals with respect to their supervisory competencies is not significant at 0.05 probability level $\left(\mathrm{t}_{118}=1.22\right)$. This implied that male and female school principals were not significantly different in their ability to supervise others in the school community. Hypothesis 1 is therefore upheld. As shown in table 2, teaching experience main effect is not found to significantly influence Principal's supervisory competency. This is so because the calculated F value 0.20 is less than the critical value, 3.39. On the other hand, considering administrative experience, the table showed that principals' supervisory competency is significantly influenced by it $(\mathrm{F} 3,119=5.03)$. The table also showed no significant interaction between teaching and administrative experiences of the subjects involved. This implied that the effect of each factor on the other was the same at all levels. Further analysis becomes necessary on Administrative experience using Multiple Classification Analysis as shown in Table 3.

From the same table, about $13 \%$ of the total variances in the supervisory processes of the principals is attributable to the variances in their administrative experience. To ascertain which level of the administrative experience mostly contributed to the observed influence, a pair wise comparison was carried out using multiple ttests.

As shown in table 4, Administrative levels 1-4 have significant influence on supervisory competencies of the school principals. Level 2 is however, found to be more influential than others. A very interesting phenomenon is discovered here, that is, principals from 610 years of administrative experience were more efficient in supervisory competencies. But from 11-15 years of administrative experience, the principals' capacity for effective supervision becomes less, and more than fifteen years of administrative experience, the principals' supervisory competencies is lesser. 


\section{Discussion}

The result showed that the mean performance of male and female principals with respect to their supervisory competencies is not significant. This finding is in consonance with that of Marshall (1984) who said that women naturally are recognized for their doggedness and effectiveness in accomplishing tasks. She opined further that women have been tested and found effective in the execution of cooperative ventures. Findings of this study however, was at variance with that of Osisioma and Nabuife (1996) which showed that female staff exhibit better leadership qualities than their male counterparts. The study of Njoku (1999) which shows that 67 percent of the respondents agreed that female school administrators exhibited poor leadership qualities is similarly not in agreement with the findings of this work. Against Njoku's findings, Marshall (1984) argued that women have a greater willingness to look at leadership not as a role prerogative of the leader but as a function invested in several qualified people. To her, the usual criticism brought against women who were said to avoid success and shun power may be better understood in terms of many women's preference for shared leadership, shared responsibilities and shared power.

As regards school principals' different teaching and administrative experiences in their supervisory competencies, the results showed that teaching experience main effect was not found to significantly influence principals' supervisory competencies. This should be expected because teaching skill is different from supervisory skill while teaching focuses on imparting of knowledge or skills and usually connotes some individual attention to the learner, supervision would require Planning, Staffing, Co-ordination, Observation, Curriculum development, and Assessment. This is why it is believed that teaching experience should not influence administrators' supervisory competencies. Conversely, findings revealed that principals' supervisory competency was found to be significantly influenced by their administrative experiences. This should be so 
because supervision is an integral part of administration. Heitzman (1981) declared that supervision is synonymous with managing.

Because supervisory competencies of the principals were found to be significantly influenced by their administrative experiences, further analysis was considered necessary to discover the levels of the significant factor. Findings revealed that administrative experience levels 1-4 have significant influence on supervisory competencies of the subject under study. Level 2, which is 6-10 years of administrative experience, was found to be more influential than others. This implied that school principals of 6-10 years of administrative experience perform better than principals with 1-3 years (level 1). Principals with 1-5 years of administrative experience perform better than principals with 11-15 years (level 3 ) while those with 11-15 years perform better than those with 15 years of experience and above. This finding supported the study conducted by the University Council on Educational Administration (1983) which stated:

In the recruitment of Administrators during the last decade a distinctive tendency developed to expand the pools from which prospective candidates are sought. Among the pools receiving greater emphasis in recruitment are women, younger persons with less experience in teaching and administration.

The reason for low in-put to many years of administrative experience of principals may be due to what the Economist term "Law of diminishing returns": The 1-5 years (level 1) of administrative experience which cannot measure up with the 6-10 years (level 2) was understandable. It may be due in part to effect of orientation as the principal is newly placed on the post.

From the findings of this study, we suggest that much more research is necessary before the total functioning of the principals as competent managers can be described. 


\section{References}

Aderounmu, W. D. \& Ehiametalor, E. T. (1985) Introduction to Administration of Schools in Nigeria. Ibadan: Evans Brothers (Nigeria Publishers) Ltd.

Gellerman, S. W. (1999). The Management of Human Resources. Hinsdale; Illinoise: the Dayden Press.

Greenfield, W. (1983). "Research on Public School Principals: A Review and Recommendations." Paper presented at the NIE Conference on Principals for Educational Excellence. Washington D.C.

Hall, D. L. (1988). "Biology, Sex Hormone and Sexism in the 1920's." In Carol C. G. and Marx, W. W. Women and Philosophy. New York: Capricon Books, G. P. Putman's Fons.

Heitzman, A. J. (1981). "School Discipline: Teachers, Students and Behaviour Management." New York: Teacher Education.

Katz. R. L. (1995). "Skills of an Effective Administrator." Harvard: Harvard Business Review (33), 1 33-42.

Knezevick, S. J. (1995). Administration of Public Education. New York: Haper and Row Publishers.

Marshall, J. (1984). Women Manager - Traveller in a Male World. London: Chichester Wiley.

Njoku, C. U. (1999). "Women Participation in Education Administration of Tertiary Insitutions in Imo State." Nigerian Journal of Vocational Teacher Education. 2 (1) 17-21.

Osisioma, H. E. \& Nabuife, K. E. (1996). "The Evolving Role of Women in Management: A Preliminary Survey." Nigeria: Journal of the Management Sciences. 36 (4), 34-40.

Sergeant, A. G. (1987). Beyond Sex Roles. New York: West Publishing.

Sergiovanni, T. J. \& Starrat, R. J. (1979). Supervision: Human Perspective. New York: McGraw-Hill

UCEA (1983). "The Preparation and Certification of Educational Administrators." A UCEA Commission Report. Columbus: Ohio.

Woodward, P. C. (1995). "A Study of Competencies needed by School Administrators and Supervisors in Virginia with Implications for Pre-Service Education." CPEA Projects, Doctorial Dissertation. Charlottesville: University of Virginia 
Figure 1: Skills needed at Various Levels

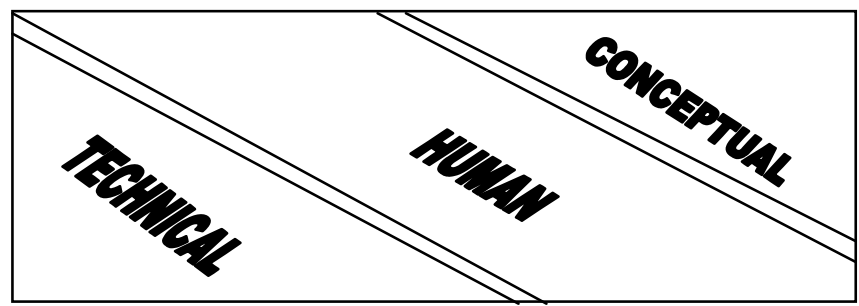

Source: Sergiovanni, T. J. \& Starrat, R. J 2nd Ed. Supervision Human Perspectives. 1979.

Table 1: $\mathrm{t}$ - test Comparison of the mean Performance of Male and Female Principals with respect of their Administrative Competence in Supervision

\begin{tabular}{|l|c|c|c|c|c|c|}
\hline $\begin{array}{l}\text { Administrative } \\
\text { competencies }\end{array}$ & Comparison & $\mathbf{N}$ & $\overline{\mathbf{X}}$ & $\mathbf{S}^{\mathbf{2}}$ & $\mathbf{t}$ & $\begin{array}{l}\text { Decision at } \\
\mathbf{P}<\mathbf{0 . 0 5}\end{array}$ \\
\hline Supervision & $\begin{array}{c}\text { Male } \\
\text { vs } \\
\text { Female }\end{array}$ & 60 & 45.27 & 25.76 & -1.22 & NS \\
\hline
\end{tabular}

Table 2: 4x4 Analysis of Variance showing the influence of Teaching Administrative Experiences on Principal's Supervisory Competencies

\begin{tabular}{|l|c|c|c|c|c|}
\hline Source of Variation & DF & SS & MS & F & $\begin{array}{l}\text { Decision at } \\
\mathbf{P}<\mathbf{0 . 0 5}\end{array}$ \\
\hline Main effects & - & - & - & - & \\
\hline Teaching Experience (TEP) & 3 & 14.30 & 4.77 & 0.20 & NS \\
\hline $\begin{array}{l}\text { Administrative Experience } \\
\text { (ADE) }\end{array}$ & 3 & 354.29 & 118.10 & 5.03 & $*$ \\
\hline 2-Way Interaction & & & & & \\
\hline TEP x ADE & 4 & 222.07 & 55.52 & 2.37 & NS \\
\hline Explained & 10 & 602.07 & 60.21 & 2.57 & \\
\hline Residual & 109 & 2558.20 & 23.47 & & \\
\hline \multicolumn{1}{|c|}{ Total } & $\mathbf{1 1 9}$ & $\mathbf{3 1 6 0 . 5 9}$ & & & \\
\hline
\end{tabular}


Table 3: Multiple Classification Analysis Showing the Levels of Administrative Experiences of Principals

\begin{tabular}{|c|c|c|c|}
\hline $\begin{array}{c}\text { Variable and } \\
\text { Category }\end{array}$ & $\mathrm{N}$ & $\begin{array}{l}\text { Unadjusted Dev'n } \\
\text { Eta }\end{array}$ & $\begin{array}{c}\text { Adjusted for Independent } \\
\text { Variables Dev'n Beta }\end{array}$ \\
\hline ADE & 51 & 0.58 & 0.74 \\
& & 1.53 & 1.48 \\
2 & 34 & -0.98 & -1.02 \\
3 & 19 & -3.95 & -4.28 \\
4 & 16 & $\mathbf{0 . 3 4}$ & $\mathbf{0 . 3 6}$ \\
\hline \multicolumn{2}{|r|}{ Grand mean } \\
\multicolumn{2}{|c|}{$\mathbf{4 4 . 1 4}$} \\
\hline
\end{tabular}

Table 4: Multiple Pair wise Comparison of the influence of different levels of Administrative experience of principals.

\begin{tabular}{|c|c|c|c|c|c|}
\hline Comparison & $\mathbf{N}$ & $\overline{\mathbf{X}}$ & $\mathbf{S}^{2}$ & $\mathbf{t}$ & $\begin{array}{l}\text { Decision } \\
\text { at } \\
P<0.05\end{array}$ \\
\hline $\begin{array}{c}\text { Level } 1 \\
\text { vs } \\
\text { Level } 2 \\
\end{array}$ & $\begin{array}{l}51 \\
54 \\
\end{array}$ & $\begin{array}{r}44.73 \\
45.63 \\
\end{array}$ & $\begin{array}{l}0.01 \\
0.07 \\
\end{array}$ & -24.36 & $*$ \\
\hline $\begin{array}{c}\text { Level } 1 \\
\text { vs } \\
\text { Level } 3\end{array}$ & $\begin{array}{l}51 \\
19\end{array}$ & $\begin{array}{l}44.73 \\
43.16 \\
\end{array}$ & $\begin{array}{c}0.01 \\
0.051\end{array}$ & 42.43 & $*$ \\
\hline $\begin{array}{c}\text { Level } 1 \\
\text { vs } \\
\text { Level } 4 \\
\end{array}$ & $\begin{array}{l}51 \\
16 \\
\end{array}$ & $\begin{array}{l}44.73 \\
40.19 \\
\end{array}$ & $\begin{array}{l}0.01 \\
0.98 \\
\end{array}$ & 33.38 & * \\
\hline $\begin{array}{c}\text { Level } 2 \\
\text { vs } \\
\text { Level } 3\end{array}$ & $\begin{array}{l}54 \\
19\end{array}$ & $\begin{array}{r}45.63 \\
43.16 \\
\end{array}$ & $\begin{array}{r}0.07 \\
0.051\end{array}$ & 36.52 & $*$ \\
\hline $\begin{array}{c}\text { Level } 2 \\
\text { vs } \\
\text { Level } 4 \\
\end{array}$ & $\begin{array}{l}54 \\
16 \\
\end{array}$ & $\begin{array}{l}45.63 \\
40.19 \\
\end{array}$ & $\begin{array}{l}0.07 \\
0.98 \\
\end{array}$ & 31.02 & $*$ \\
\hline $\begin{array}{c}\text { Level } 3 \\
\text { vs } \\
\text { Level } 4 \\
\end{array}$ & $\begin{array}{l}19 \\
16 \\
\end{array}$ & $\begin{array}{l}43.16 \\
40.19 \\
\end{array}$ & $\begin{array}{l}0.051 \\
0.98 \\
\end{array}$ & 12.53 & $*$ \\
\hline \multicolumn{6}{|c|}{ Level $2>$ Level $1>$ Level $3>$ Level 4} \\
\hline
\end{tabular}

